\title{
DWUGŁOS O BUDOWNICZYM. O IZABELI WAGNER I ARTURA DOMOSŁAWSKIEGO BIOGRAFIACH ZYGMUNTA BAUMANA
}

\section{Joanna Tokarska-Bakir ${ }^{*}$}

Abstrakt

Artykuł zestawia ze sobą i problematyzuje dwie godne odnotowania biografie wybitnego socjologa i filozofa społecznego, Zygmunta Baumana, autorstwa Izabeli Wagner i Artura Domosławskiego, dokonując analizy zawartego w nich przekazu na tle powojennej polskiej historii politycznej i kulturowej.

Słowa kluczowe: Zygmunt Bauman, Izabela Wagner, Artur Domosławski, antysemityzm powojenny, polityka historyczna

\section{TWO VOICES ON THE BUILDER.}

\section{IZABELA WAGNER AND ARTUR DOMOStAWSKI ON ZYGMUNT BAUMAN}

Abstract

This paper crisscrosses and binds two remarkable biographies of renowned sociologist and social philosopher Zygmunt Bauman: that by Izabela Wagner and Artur Domosławski, juxtaposing their messages against the background of Polish postwar political and cultural history.

Keywords: Zygmunt Bauman, Izabela Wagner, Artur Domosławski, postwar antisemitism, historical policy

* Prof. dr hab. Joanna Tokarska-Bakir, Instytut Slawistyki PAN, Warszawa, Polska e-mail: joanna.tokarska-bakir@ispan.waw.pl ｜ＯRCID: http://orcid.org/0000-0003-4778-0465 
Zaraz gdy na wolnej od Niemców Pradze zaczęły się tworzyć pierwsze komitety PPR, napisał do nich Władysław Gomułka:

\begin{abstract}
„Rozmawiałem ostatnio z kilkoma ludźmi o pracy i stanie naszej organizacji partyjnej na Pradze. Opinia wszystkich towarzyszy sprowadza się mniej więcej do jednego wniosku: źle dobrany Komitet Warszawski, a zwłaszcza skład narodowościowy Komitetu utrudnia rozwój organizacji warszawskiej. (...) Musicie zbudować Komitet Warszawski z polskich, miejscowych towarzyszy. Muszę Wam podkreślić, że szczególnie niemile widziani są towarzysze żydowscy, którzy nie pracowali w kraju w czasie okupacji. Mimo znacznej wartości, jaką oni przedstawiają od strony wyrobienia partyjnego, nie możemy stawiać ich na zbyt eksponowane posterunki partyjne. Mogą oni i powinni służyć radą i doświadczeniem towarzyszom polskim, lecz za nich roboty nie zrobią, tzn. mimo swego wyrobienia politycznego nie potrafią rozbudować wszerz naszej organizacji”.
\end{abstract}

Tak właśnie, zanim jeszcze skończyła się wojna, został zdefiniowany problem, który ćwierć wieku później wypędził Zygmunta Baumana z kraju. Wstydliwy problem poszerzania bazy rozumianej po endecku, „nacjonalistyczny bolszewizm”2, który PPR odziedziczyła po KPP, dzieląc go z PPS, potem zaś przekazała następcom. Z tym problem do dnia dzisiejszego borykają się w Polsce wszystkie siły nie usatysfakcjonowane ideałem anima naturaliter endeciana, i każda, bojąc się łatki „partii żydowskiej”, omija go jak może. Donald Tusk powiedział kiedyś buńczucznie: „Poradziliśmy sobie z antysemityzmem, poradzimy z chamstwem w polityce”. I niewiele się pomylę twierdząc, że był to pierwszy i ostatni raz, kiedy to słowo publicznie wypowiedział. Analogiczne stanowisko, z opinią, że „sprawa żydowska nie ma w sobie kapitału politycznego”, można

\footnotetext{
1 Władysław Comułka, list z 6/1/1944, Teczki osobowe, AAN, sygn. 7432, k. 85.

2 Jest to określenie Zygmunta Baumana, którego używa w wywiadzie z Peterem Haffnerem, cyt. za Domosławski 2021: 233. Dalej używane są odsyłacze w formie skróconej: W - Wagner 2021; D - Domosławski 2021.
} 
było usłyszeć w kręgu wczesnej „Krytyki Politycznej”3. W Polsce temat na „亡̈” wciąż stanowi pocałunek śmierci, co oznacza, że warunki, które wygnały Zygmunta Baumana z kraju, nie tylko nie zniknęły, ale mają się coraz lepiej.

\section{Niech zakwitnie tysiąc kwiatów}

Dwie biografie Zygmunta Baumana, o których będę tu mówić, przyjmują wobec tego problemu odmienne strategie. Izabela Wagner, której angielska wersja biografii (Wagner 2020) przetarła szlaki, uważa go za sprężynę opisywanego życia, obudowuje socjologicznym konkretem i posługuje się techniką iteracji - coraz większych przybliżeń. Artur Domosławski, jakby chcąc nadrobić opóźnienie, sygnalizuje go już w tytule i wali „między oczy”. Zadziwiająca fuzja zachodzi pomiędzy tymi dwiema nieantagonistycznymi narracjami, które uzupełniając się nawzajem urzeczywistniają Baumanowskie marzenie: „niech zakwitnie tysiąc kwiatów" (W: 338; D: 532).

Ten szczególny sposób opowiadania biografii, wktórej centrum też zawsze stoi zagadka, sprawia, że i Wagner, i Domosławski nie rozstrzygają niczego ani za bohatera, ani za czytelnika. W efekcie oprócz portretu Baumana otrzymujemy przejmujący obraz polskiego społeczeństwa starszego i średniego pokolenia, które mimo świetnego samopoczucia, nie nadąża za zmianami, co skutkuje obecnym stanem rzeczy w kraju .

\footnotetext{
3 Zanotowałam w roku 2018 po rozmowie z Zofią Waślicką-Żmijewską. Poznałam też oczywiście nazwisko głosiciela tej opinii, które tu pomijam.

4 Rozwinięcie zasługiwałoby na projekt badawczy, więc zasygnalizuję tylko najważniejsze zagadnienia: chodzi o niedoszacowanie przez socjologów i psychologów społecznych poparcia dla polityki autorytarnej przed objęciem władzy przez PiS, o poparcie dla „polityki historycznej” PiS, a wcześniej PO (z inicjatywy prezydenta Bronisława Komorowskiego w lutym 2010 wprowadzono święto tzw. ,żołnierzy wyklętych”; Sejm RP, którego marszałkiem była posłanka PO Ewa Kopacz, 9 listopada 2012 roku jednomyślnie przegłosował uchwałe, że NSZ dobrze zasłużyły się ojczyźnie, zob. Monitor Polski 2012, nr 890), dla „reform” redukujących obszar wolności obywatelskich, o sposób przeciwstawiania się ksenofobii i antysemityzmowi, w tym o zarządzanie
} 
Obie książki są do bólu rzetelne, alejedna jest książką socjolożki, a druga - dziennikarza. Nie chodzi tylko o fantastyczne przypisy Wagner, które można czytać jako zaawansowany kurs biografistyki i socjologii pracy, ani o kunsztowną anachroniczną konstrukcję książki Domosławskiego. Przy uważnej lekturze wychodzą na jaw różnice wrażliwości autorów, jak choćby w detalu, od którego zbiegiem okoliczności rozpoczynają oboje. To scena wkroczenia NOP-owskiej bojówki na wrocławski wykład Baumana w czerwcu 2013, w dosłownym znaczeniu finał jego obecności w Polsce, a jeszcze bardziej przenikliwa diagnoza przyszłości kraju. „Bauman siedzi osamotniony na scenie - wygląda na załamanego", pisze Wagner (W: 10). A co widzi Domosławski? „Po kilku minutach wysłuchiwania okrzyków, mowa jego ciała zdradza zniecierpliwienie” (D: 13). J akże zazdrościmy Baumanowi kulis, w których się utedy rozpłynął!

I choć Domosławski ma rację, że bezpośrednią reakcją na ten eksces było nerwowe zerwanie, trudno nie zgodzić się z Wagner, która mówi o klęsce. Klęsce projektu rozumienia i porozumienia, i odkupienia przez porozumienie, na co Bauman niezaprzeczalnie liczył. Odnosząc się do starego sporu z ojcem syjonistą, pisał proroczo w połowie lat 80. XX wieku:

\begin{abstract}
„Wierzyłem chyba, że wystarczy wola moralna, by pokonać opór nastrojów plemiennych. I chyba byłem nieświadomy tego, że w walce z nieprzepartymi przeszkodami wola moralna może utracić jedyne źródło swojej siły i jedyny tytuł do szacunku: czystość etyczną. Gdy tak się staje, nie ma większego wyboru między nieludzkością woli i nieludzkością plemienia. Tego miałem się dopiero dowiedzieć, i to w sposób nie do pozazdroszczenia..." (W: 104).
\end{abstract}

kryzysami po szykanach jakie spotykały Zygmunta Baumana ze strony politycznej chuliganerii, a nawet o inicjowanie tych szykan (piszę o tym dalej w części związanej z odrzuceniem wniosku ISNS UW o odnowienie doktoratu Baumana). 
Gdyby zgadywać, dlaczego po wrocławskim (i poznańskim) ataku postanowil już do Polski nie wracać, nie wystarczy wskazać „nastroje plemienne”. Zawód dotyczył czegoś głębszego, czegoś, co zachwiało podstawami jego wiary w rozmowę. Cenną poszlakę - w postaci słowa „zdrada”- zawdzięczamy uważności Wagner. Biografka odkryła tę różnicę, porównując warianty książki J aniny Bauman Nigdzie na ziemi:

„Wracając do lat sześćdziesiątych, nigdy nie przypuszczaliśmy, że to się tak skończy: zdradami i rozstaniami (...). Żyliśmy pełnym, szczęśliwym życiem i mieliśmy silne poczucie przynależności” (Bauman 2009, za: W: 378).

Czy słowo „zdrada” usunięto z wydania polskiego, bo za dużo odsłaniało? ${ }^{5}$ Tego nie wiemy, możemy jednak być pewni, że nie zgadzało się z maksymą życiową, którą socjolog odziedziczył po ojcu, Maurycym Baumanie (1890-1959): „Życie nie może upokorzyć człowieka, który się nie skarży. To skarga czyni życie upokorzeniem” (D: 29).

A więc zdrada: pierwszy raz przez towarzyszy z KBW, dla których pozostał Żydem. Drugi raz przez marcowych docentówin spe, oskarżających go o syjonizm. A po raz trzeci (i czwarty, według rachuby Domosławskiego, D: 800) - przez przyjaciół, w których zdolność osądu dwóch pierwszych okoliczności przedwcześnie uwierzył.

Z tej ostatniej katastrofy, której rozbłyskami usiane są obie biografie, pełne protekcjonalnych, nieczułych wypowiedzi warszawskiej elity, Bauman już się nie podniósł.

\footnotetext{
5 Wagner (2021) pisze dalej: „Polska wersja tekstu jest napisana z większym dystansem, autorka «gubi» słowo «zdrada». Kryje się za nim zachowanie niektórych przyjaciół, którzy w trudnej sytuacji w 1968 roku stchórzyli: «We wczesnych latach sześćdziesiątych nie przyszłoby nam na myśl, że wkrótce będzie trzeba rozstać się ze wszystkim, co było nasze: z domem, krajem, językiem, przyjaciółmi»” (W: 378). Temat wraca na W: 471.
} 
„Wielu rozmówców, zdawałoby się Baumanowi przychylnych, wypowiada się o nim z nutą lekceważenia i wyższości. Towarzyszą temu asekuracyjne zastrzeżenia, żeby te ich uwagi, podważające reputację Baumana jako wybitnego umysłu, nie były cytowane pod nazwiskiem" (D: 362).

W krajowej sławie Zygmunta Baumana jest tyle jadu i toksyn, że ktoś powinien wystąpić o grant europejski na systematyczne studium polskiego piekła. Niedobrze się robi, gdy naukowe miernoty wzgardliwie komentują dwadzieścia Baumanowskich doktoratów honoris causa i książki przełożone na trzydzieści języków. Zbyt duże osobiste stawki zostały w tę pogardę zaangażowane, by recenzowane biografie coś w tym chórze zmieniły. Wypada się jednak cieszyć, że sprostują niejedno pomówienie, ukazując np. małostkowe tło intryg, które storpedowały ideę odnowienia doktoratu Baumana na UW (W: 618-622), albo nieżyczliwą interpretację faktu, że w roku w 1968 Bauman nie poparł listu profesorów, wzywającego do wiecu. Nie poparł, wyjaśnia Wagner, bo „nie był już członkiem partii - nie był też jeszcze profesorem” (W: 442). Ale gdy milicjanci wpadli do budynku IFiS-u za studentami, którzy się tam schronili, to właśnie on, przeciwnik wiecu, ich zatrzymał (W: 441, D: 424)6 W 1968 Bauman został wytypowany jako kozioł ofiarny nie dlatego, że był przywódcą marca (którym nie był), ale dlatego, że jak każdy kozioł po prostu się do tego nadawał.

Komentując getto ławkowe, którego doświadczył w poznańskim gimnazjum, Bauman pisał:

„Nikt spośród moich nauczycieli, czy kolegów nie-Żydów nie próbował przeciwstawić się «życiowym faktom». Podział był solidny i trwały, gdyż ci, którym na

\footnotetext{
${ }^{6}$ Inne nieporozumienie wiąże się np. z wywiadem dla izraelskiego pisma „Maariv” z 20/10/1968, którego dziennikarz-mitoman dopisał Baumanowi opinie, których ten wypowiedzieć po prostu nie mógł (D: 457, 490).
} 
nim zależało, byli aktywni, podczas gdy ci, którzy go nie uznawali, przyglądali się tylko" (W: 56; D: 52).

Trudno o lepszy komentarz do „sprawy Baumana”, a zarazem do najnowszych dziejów Polski.

Determinizm i odwet

Stanisław Brzozowski uważał, że co nie jest biografią, nie jest w ogóle. Bauman nie zgadza się z Brzozowskim. W książce Wagner wielokrotnie podkreśla, jak mierzi go biograficzny determinizm (W: 7, 12, 657). Ale w cytowanej przez Domosławskiego konkluzji zapomina o tym i stwierdza: „Innego życia mieć nie mogłem” (D: 23).

Przytaczający jego słowa dopatruje się w nich prośby o zrozumienie. Po czym pisze: „Możliwe, że Bauman podejmował decyzje i dopuszczał się czynów, które zasługują na krytyczną ocenę, niechęć czy nawet potępienie" (D: 23). I postuluje wyłącznie umotywowane oceny.

J est pewna naiwność w tej postawie. „Krytyczna ocena” życia tak długiego, podlegającego regułom tylekroć zmienianym, to darmowa rozrywka mająca więcej wspólnego z asystowaniem przy publicznej egzekucji niż z refleksją moralną. Pół biedy, gdy uczestniczą w niej miłoszowscy ludzie „cisi i ciemni”. Biograficzny voyeryzm i polityczne klakierstwo to dziś rozrywka nie tylko plebejska. Z uprzywilejowania, lenistwa i zaniechania powstaje ignorancja historyczna, wina, którą Domosławski sytuuje w środowiskach „liberalnych, czasem lewicowych” (D: 17). Ale niekiedy sam pod ten zarzut podpada. Wyjaśniając atmosferę powojnia Domosławski - w odróżnieniu od Wagner - przyjmuje uproszczoną leksykę, wyznaczającą nieprzekraczalną normatywność, bez poddawania jej pod dyskusję. W roli autorytetów przywołuje strażników 
antykomunistycznego status quo (np. Tomasza Łabuszewskiego, D: 169, Grzegorza Motykę etc.). Aprioryczne rozstrzygnięcia w tym nurcie historii są widoczne „na wejściu”: w określeniach takich jak „podziemie niepodległościowe”, czy w cenzurowaniu określenia „wyzwolenie”, nawet gdy dotyczy ono żydowskich Polaków ratowanych od śmierci przez Armię Czerwoną7. Wpływ widać w stosowanych przez Domosławskiego kategoriach opisu, np.: „Wolińska była w latach stalinizmu prokurator oskarżającą wrogów Polski Ludowej” (D: 579), pytanie o KBW jako ,janczarów komunizmu” (D: 157), czy opinia, że podporucznik Bauman „bronił powojennej władzy przed zbrojnym podziemiem” (D: 516). Wszystkie zostały zbudowane - dosłownie - na czarno-białych schematach antykomunizmu. Na stronie 786 pisząc o Baumanie, który walczył $\mathrm{z}$ „przeciwnikami nowego porządku”, autor przeciwstawia sobie „partyzantów” i „szabrowników” (D: 786), co świadczy o niepogłębionej wiedzy o powojennych realiach. Nie sposób odrzucić hegemonii kulturowej nie poznawszy tych realiów.

U Domosławskiego uosobieniem ignorancji, uprzywilejowania i zaniechania jest warszawska profesorka socjologii, informująca go, że w czasie walk o Wał Pomorski, Bauman-politruk „strzelał w plecy żołnierzom, którzy się wycofywali” (D: 16). Zupełnie nie dziwi podsumowująca temat wzmianka, że w czasach studenckich ta sama pani profesor przeżywała fascynację Zygmuntem Baumanem.

Powyższy casus to nie czcza anegdota. Zdaniem Domosławskiego w nagłośnianiu „sprawy Baumana w KBW” chodziło o „symboliczny odwet” (D: 193), jednak w omawianym przypadku to raczej o „łapaj złodzieja”, odwrócenie uwagi od własnych czynów i sympatii. Łatwo i przyjemnie

\footnotetext{
7 Pisałam o tym (Tokarska-Bakir 2016) przy okazji ocenzurowania przez prof. Andrzeja Friszkego terminologii używanej na wystawie o powojniu w Muzeum Polin przez jedną z jej autorek, socjolożkę i byłą szefową warszawskiej gminy żydowskiej, dr Helenę Datner.
} 
jest myśleć o sobie jako o „lawie”, chociaż się nigdy nie wybuchło. Wyobrażenie o peerelu jako o patriotycznej guerilli rozwiewa pierwsza lepsza kwerenda w IPN.

Alei kategoria odwetu znajdzie swoje zastosowanie. Ze względu na local knowledge miejsca, gdzie rozegrała się Zagłada, na środowisku polskich socjologów spoczywała szczególna odpowiedzialność poznawcza i obywatelska. Niestety nie wynikły z niej żadne przełomowe prace - ani na temat nowoczesności, ani Zagłady. Książka Baumana z nimi obiema w tytule budziła niechęć, bo konfrontowała z tym zaniechaniem. Sugestię socjologii, mającej mniej do powiedzenia o Zagładzie niż Zagłada o socjologii (Bauman 2009: 27), wielu odczytało osobiście9.

Bauman ogromniesię rozwinął, odkąd został z Polski wyrzucony, podczas gdy ci, którzy w niej zostali, szlifowali wciąż ten sam, teraz już nieskrywany antykomunizm i frustrację. Trudno im było fetować kolegę, gdy wracał opromieniony światową sławą, z naręczem pomysłów, wielbiony przez młodych. Więc wskazano mu miejsce w szeregu: był przecież politrukiem z KBW, niezasługującym na to, by wzorowała się na nim młodzież ${ }^{10}$. Tak w każdym razie uznała rektor Uniwersytetu Warszawskiego,

\footnotetext{
${ }^{8}$ W dokumencie WiN pt. Oświadczenie w sprawie wyborów w Polsce z roku 1946 czytamy, że w Polsce jest „ponad 300 tysięcy [ludzi] w UB, KBW, MO i ORMO”. Jeśli chodzi o zwolenników komunizmu, ,jedynie 25 tysięcy [jest] szczerych zwolenników i około 500 tysięcy zwolenników koniunkturalnych", Archiwum Narodowe w Krakowie, Zespół WiN 9, k. 279.

9 Afront nie zostanie Baumanowi zapomniany. W roku 2011 Rada Naukowa ISNS skreśliła Baumanowską Nowoczesność i Zagładęz listy lektur do egzaminów wstępnych, tłumacząc to niewybieraniem tej pozycji przez studentów.

${ }^{10}$ List Komisji do Spraw Tytułów Honorowych UW sugerował, że odnowienie doktoratu to uroczystość związana z docenieniem „nie tylko dokonań naukowych, ale także wzorców postawy obywatelskiej” (W: 627). Jak zauważa Izabela Wagner, nikt nie odmówił postawy obywatelskiej innym uhonorowanym przez Uniwersytet osobom, takim jak Juliusz Bardach czy Dawid Shugar, oskarżany o szpiegostwo na rzecz ZSRR (W 626). Domosławski zwraca uwagę, że wszystkie możliwe laury na UW uzyskał Leszek Kołakowski, ideologiczny poputczik Baumana, który wprawdzie też chodził „z pistoletem w kieszeni”, ale potem przykładnie nawrócił się na antykomunizm.
} 
prywatnie córka socjologa, który w marcu 1968 dokładał do pieca11, a wcześniej jako piewca „uniwersytetu socjalistycznego” siadywał w loży obok Stalina (W: 305). Poczucie wstydu wzmagają cytowane przez Domosławskiego i Wagner wypowiedzi uniwersyteckich autorytetów: prof. Węgleńskiego, Siwickiego, Białynickiego-Biruli (D: 773-777), Axera. Widać małość i zawiść. Także Henryk Samsonowicz, w roku 1981 rektor UW, który w swoim czasie przepraszał Baumana za wyrzucenie z uczelni, dołączył do obłudnego chóru „oburzonych”. Domosławski ma rację pisząc, że gdy zapadła decyzja o odmowie odnowienia doktoratu, nie było środowiska, które by Baumana broniło (D: 15). Wagner tłumaczy dlaczego: „Samą swoją obecnością przywracał pamięć o tym, co się stało w 1968 roku. (...) Był chodzącym świadkiem udaru mózgu Polski, która ma kłopoty z dojściem do zdrowia nawet kilkadziesiąt lat po wypadkach" (W: 627).

Jako osoba, która na radzie jednego z wydziałów UW zgłosiła w roku 2006 wniosek o odnowienie doktoratu Zygmunta Baumana, chciałabym wyjaśnić powód, dlaczego część z nas złożyła wówczas broń. Po rozmowie w rektoracie to profesor Aldona Jawłowska zdecydowała, że przyniesie to więcej szkody niż pożytku. Usłyszeliśmy, żedzieląc się wątpliwościami co do morale socjologa, rektor Katarzyna Chałasińska-Macukow posłużyła się wówczas teczką Baumana z archiwum UW. Wyjęła z niej oświadczenie cytowane przez Domosławskiego:

„We fragmencie o ojcu [Bauman] stwierdza, że «zachował nadal swe syjonistyczne poglądy, wskutek czego coraz bardziej pogłębia się rozdźwięk między nim, a resztą rodziny». Następnie pada deklaracja: «w styczniu 1953 ostatecznie zerwałem wszelkie stosunki z ojcem»" (D: 285, inna wersja oświadczenia w W: 279).

\footnotetext{
"D: 330, 369: „Chałasiński sformułował tezę o wpływie żydowskiego pochodzenia na poczucie wyalienowania”. D: 432-433 - o eseju Józefa Chałasińskiego pt. Niepokojące zjawiska z „Trybuny Ludu” 24/3/1968 (miażdżąca krytyka Kultury i społeczeństwa Zygmunta Baumana).
} 
Tylko w Polsce możne się zdarzyć, aby córka człowieka, który walczył z syjonizmem (Dąbrowski et. al, red., 2018: 157), broniła syjonisty przed synem antysyjonistą, którego wyrzucono z kraju za syjonizm.

Czy więc leitmotivem życia Baumana była przegrana z piętnem? Ze sprzecznych sądów o determinizmie wynika być może, że szło mu nie tyle o niezgodę na redukcję do piętna, ile o wolność, perspektywę szczęścia pomimo piętna. Ten element akcentuje Sheila Fitzpatrick (2020), która w świetnej recenzji z książki Wagner w „London Review of Books” stwierdza, że „Bauman nie tylko uparcie odrzucał rolę ofiary, lecz także udało mu się uzyskać unikalny status (...) człowieka szczęśliwego". Z perspektywy polskiego piekła wyczyszczonego z Baumanów to wybaczyć było chyba najtrudniej.

\section{Żydokomuna i KBW}

Polska jako społeczeństwo ma przed sobą debatę o komunizmie, ale jak dotąd zastępczo dyskutuje o żydokomunie, której Bauman jest klasycznym przykładem. Za stan debaty publicznej w tej sprawie w znacznym stopniu odpowiadają socjologowie, którzy nie tylko nie rozmontowali fałszywych kategorii polityki historycznej, ale dostarczyli jej nowych narzędzi (zob. Śpiewak 2012²).

\footnotetext{
12 Rzeczowa krytyka w recenzji prof. Augusta Grabskiego (2012). Wcześniej, do powszechnego lekceważenia problemów narastającego antysemityzmu (w tym obecności przekazu o tzw. żydowskim mordzie rytualnym, uznawanej za śladową) prowadziły wnioski z badań sondażowych, podsumowane w książce pod redakcją Ireneusza Krzemińskiego (1996), Czy Polacy sq antysemitami?. Socjologowie unikali metody etnograficznej, która pozwala odróżnić deklaracje od faktycznych postaw. Niewłaściwie interpretowali też dane (zob. Antoniego Sułka przekonanie, że ogromne przeszacowanie liczby Żydów w Polsce nie wskazuje na postawy antyżydowskie). Nic dziwnego, że ich wyniki różniły się od rezultatów badań np. Aliny Całej (2005), która stosowała metody etnograficzne konsekwentnie już w latach siedemdziesiątych XX wieku (zob. także Tokarska-Bakir 2008), czy jej następcy, np. Pawła Buszki (2012). Ciekawą woltę zastosował psycholog społeczny Michał Bilewicz (2009), który od „przeoczenia” wątków mordu rytualnego sprawnie przeszedł do specjalizacji w tym zakresie. Zob. jego opinia z roku 2009: „,... twierdzenie na podstawie
} 
Uczestników debat o „nadreprezentacji Żydów w komunizmie” nie szokują przyczyny, czyli skala wykluczenia Żydóww II RP, szokujeich tylko jego skutek, reakcja na wykluczenie ${ }^{13}$, co legalizuje agresywne fantazje o Żydach. Agresję tę widać w omawianej przez oboje biografów legendzie o pistolecie, który kiedyś podobno wypadł Baumanowi z kabury (W: 630; D: 236, 777), a także opowieści o jego inkwizytorskich zapędach, gdy publicznie przepytywał kandydatów do PZPR (D: 235). Czego nie widać zza tych opowieści? Może ludzi, którzy tłumnie się do partii zapisywali?

Komunizm „był nadzieją, obietnica, cudowną opowieścią”, pisze Alona Frankel (2007: 38), która spędziła wojnę najpierw w skrzyni w oborze, a następnie przeniosła się do szafy. Stalin jej obiecał, że także „na jej ulicy będzie święto”, więc dziewczynka pokochała Stalina. Koniec wojny opisuje tak:

\begin{abstract}
„Absolutne dobro pokonało absolutne zło. Mam 7 lat. Teraz wszystko zmieni się na lepsze. Świat będzie coraz doskonalszy. Ustaną wojny. Człowiek przestanie wyzyskiwać człowieka. Nikt nie będzie dyskryminowany, każdy będzie mógł zabezpieczyć swoje dzieci, żeby były zdrowe, żeby miały książki i nie głodowały" (Frankel 2007: 40).
\end{abstract}

\footnotetext{
badań przeprowadzonych w wyludniających się regionach kraju, że odkryło się prawdę o współczesnej Polsce, wydaje się daleko idącym nadużyciem. Dzisiejsza Polska to nie tylko - a nawet głównie nie - mieszkańcy podsandomierskich i podlaskich wsi. Dzisiejsza Polska to raczej Londyn, Warszawa czy Poznań (biorąc pod uwagę kierunki migracji). (...) Doprawdy trudno odnaleźć Polskę Tokarskiej-Bakir na warszawskiej ulicy. Również w Krakowie, w Gdańsku czy Wrocławiu".

13 Komentarz Baumana do tej sprawy: „Nie uważam już, by było rzeczą wartościową lub mądrą z punktu widzenia Żydów uczestnictwo w walkach narodu w Europie Wschodniej. Po jakimś czasie to wszystko, czego Żydzi dokonali dla kraju, w którym żyli, i tak zostanie wykorzystane przeciw nim. Tak się stało na przykład z Żydami, którzy walczyli w armii radzieckiej z nazistami. Nawet to zostało wykorzystane, by ich obwinić, że byli agentami szerzącymi radzieckie wpływy w rejonie... [W] tej części świata istnieje tradycja obsadzania Żydów w roli kozłów ofiarnych", cyt. za D: 600.
} 
W roku 1945 Zygmunt Bauman był wprawdzie o dziesięć lat starszy od dziewczynki, ale mógł to odczuwać podobnie. Czy oboje mieli jakieś inne wyjście niż komunizm? Owszem: wyjazd do Palestyny, na który ojciec Alony zdecydował się po entym liście z pogróżkami. Kto zwlekał lub skręcił do lasu, kończył jak bohaterka noweli Stanisława Benskiego Ocaleni, pogrzebana w swoim lesie razem z zajączkami, zaskrońcem i wiewiórką (Benski 1986: 144-146).

Bauman nie zamierzał ani wyjeżdżać, ani iść do lasu. Czuł się Polakiem i służył w KBW, odkąd 4 dywizja WP została przemianowana na formację o tej nazwie. J ego służba przypadła na wiosnę 1946, kiedy powstała poniższa ulotka WiN-u:

„[Komenda Powiatowa MO w Nowym Sączu pisze:] Dnia 4/3/1946 zostały rozlepione przez nieznanych osobników w Grybowie ulotki po tablicach ogłoszeń i stupach telefonicznych. (...) «Obywatele! Blisko 6 lat krwawej niewoli niemieckiej pozostawiło na obliczu społeczeństwa polskiego, przeoranego bruzdami Oświęcimia, Majdanka, i innych katowni hitlerowskich, tragiczne piętno demoralizacji. Najgroźniejszym jej przejawem jest szerzący się dzisiaj zastraszający bandytyzm, wartość życia ludzkiego spadła do minimum, a obniżanie poczucia cudzej własności przybiera zastraszające formy i rozmiary. Wykolejone zbrodnicze jednostki wykorzystują obecnie bohaterskie zmaganie się ideowych elementów w walce o wolność obywatelską i niezawisłość bytu narodowego, zagrożoną przez czerwony imperializm wschodu, prowadząc swą bandycką i rabunkową działalność. Wraża propaganda wykorzystuje te momenty, przypisując je organizacji ideowo-politycznej, i wbłocie oszczerstw nurza najszczytniejsze porywy bojowników o świętą dla każdego prawdziwego Polaka sprawę. Dla każdego trzeźwo myślącego obywatela jasnym powinno być, że mnożące się z każdym dniem napady bandyckie i rabunkowe, którym niedołężny aparat bezpieczeństwa zapobiec niejest w stanie, nic wspólnego z ruchem podziemnym nie mają. Ufamy, że społeczeństwo polskie potrafi odróżnić metody walki elementówideowych od zwykłych 
bandyckich wyczynów, i w zrozumieniu grożącego niebezpieczeństwa ułatwi zwalczanie tychże. Kierownictwo Rady Powiatowej Podziemnego Ruchu Wolnościowego»"14.

Ulotka, która prawdopodobnie była odpowiedzią na mordy grupy J ózefa Kurasia-„Ognia”15, odmalowuje stan bezpieczeństwa na prowincji. To właśnie na ten stan rzeczy władze reagowały organizując obławy KBW, i znękana wojną prowincja często reagowała na nie wdzięcznością ${ }^{16}$.

\section{Domosławski zwraca uwagę na nagły przypływ miłości Polaków do tej} formacji, gdy w roku 1956 wojska radzieckie szły na Warszawę. Ale po latach antykomunistycznego prania mózgu, ten pojedynczy paradoks nikogo nie przekona. O sile złudzeń, pleniących się na gruncie polityki historycznej, świadczy zdanie z pierwszorzędnej książki Magdaleny Grochowskiej, która komentując obyczaj chodzenia z bronią partyjnych

\footnotetext{
14 Wykaz przestępczości za miesiąc marzec 1946, Powiatowa Komenda MO Referat Śledczy Nowy Sącz, AIPN, Kr 140/591, k. 1. Przekazanie ulotki przez KP MO w Nowym Sączu oraz pewne stwierdzenia w tekście stanowią gwarancję autentyczności źródła.

1529 stycznia 1946 w Zakopanem zamordowano Józefa Oppenheima. 10 lutego 1946 w Nowym Targu zamordowano Dawida Grassgrüna. 20 kwietnia 1946 w Nowym Targu zamordowano Ludwik Herza, Salomona (Lonka) Lindebergera, Beniamina Rose, Henryka Unterbucha, Ruth Joachisman. 30 kwietnia 1946 w miejscowości Groń/Białka zamordowano Blimę Krebs, Beilę Gold, Fridę Salzberg, Feigę Schwerdszarf, Chaskla Świecznika, Sarę Dornberg, Salomona Dornberga. 2 maja 1946 1 km przed Krościenkiem od strony Nowego Sącza zamordowano Izraela Piniuńskiego (zmarł w szpitalu), Rachelę Piniuńska, Temę Holand, Rachelę Holand, Dwojrę Wygodę, Abrahama Wygodę, Izrael Flama, Rachelę Szapiro, Libę Szapiro, Jakuba Finkelsteina, Mosze Szmulewicza (prawdopodobnie), Józefa Gallera, Reginę Schlosser (zmarła w szpitalu). Zob. Panz 2015.

${ }^{16}$ „Jak wynika z raportu starosty puławskiego, wprost entuzjastycznie reagowano na «akcję rozpoczętą przez KBW przeciwko działalności band», zakończoną wyrokami Sądu Doraźnego na sesji wyjazdowej w Puławach. «Nie wyczuwa się ze strony społeczeństwa nieufności do Sądu z przyczyn politycznych, raczej uważa się, że skazani na śmierć są bandytami, których ręka sprawiedliwości dosięgła. Społeczeństwo zwraca uwagę na młodociany wiek oskarżonych, ich tępotę umysłową, często analfabetyzm i z powodu tego uczuciowo jest wielka nienawiść do tych, którzy kierują akcją bandycką». Reasumując, pisze starosta, «działalność Sądu Doraźnego wpłynęła ogromnie na uspokojenie umysłów, na ustabilizowanie władzy administracyjnej, na porządek i wykonywanie zleceń przełożonych (...) zniknęły morderstwa, rabunki, kradzieże, napady. (...) Ludność zaczęła wypełniać powinności, oddając świadczenia, płacąc podatki. (...) Stawiam więc wniosek, aby oddziały KBW i Sąd Doraźny pozostały dłuższy czas, aby przed wyborami uspokoić powiat na dobre»", cyt. za: Tokarska-Bakir 2018: 158-159, za: Sprawozdanie informacyjne za miesiąc sierpień 1946. Teren krakowski, ANKr, WiN 4, 157.
} 
aktywistów pisze: „Żyją $w$ poczuciu zagrożenia, więc muszą nosić nagany pod ubraniami" (D: 242; W: 294). Grochowskiej dedykuję ulotkę z roku 1946, skierowaną już bezpośrednio do ludzi takich jak Bauman.

\begin{abstract}
„Ostrzeżenie. Do oddziałów wojsk czerwonych, wojsk Polski demokratycznej, UB, KBW i Milicji Obywatelskiej. Grupy lotne AK wydają do Powiatowego Urzędu Amnestyjnego w Żywcu ostatnie ostrzeżenie [wzywając do] zaniechania obław. 1. Wszyscy złapani w lesie z bronią, działający na naszą szkodę, będą rozstrzeliwani. 2. Obywatele pomagający w prowadzeniu obław lub też wskazujący miejsce pobytu partyzantów, zostaną powieszeni. Skorzystamy przy najbliższej okazji z pozwolenia i zgłosimy się na posterunkach UB i MO - z granatami, w celu pomszczenia braci partyzantów. Partyzant jest przygotowany na to, że wpadłszy w wasze żebracze ręce zostanie rozstrzelany. J ego zdecydowanie zapadło przy oddaniu przysięgi. Więc strachy na lachy!"
\end{abstract}

Tu pojawia się „narodowo” skorygowana pieśń:
„Czy przyjdzie nam umrzeć wśród pól,
Czy w tajgach Sybiru nam zgnić,
Z trudu naszego i znoju
Polska dla Polaków powstanie, by żyć”.

\title{
I finał:
}

„Wzywamy wszystkich Polaków do przeciwdziałania naszemu drugiemu po hitlerowskim okupantowi bolszewickiemu. Niech żyje Polska narodowa!!! Precz z komuną!!! Za zerwanie afiszu kara śmierci!! Dowódca Narodowych Sił Zbrojnych Grup Leśnych Śląska Cieszyń[skiego]”17.

\footnotetext{
${ }_{17}$ Raporty dekadowe, ulotki i inne materiały z 1945-1946, AIPN, Kr 031/2 tı, k. 38
} 
J est raczej jasne, co stałoby się z Zygmuntem Baumanem, gdyby stanął na drodze temu dowódcy.

O tym samym zapewniają inne ulotki z epoki. Na przykład pieśn zwana rotą $\mathrm{PPR}^{18}$. Wygląda na niegroźny folklor, ale opiera się na dehumanizacji. Symboliczna likwidacja ludzkiego przeciwnika poprzedza i ułatwia likwidację fizyczną, a po wszystkim minimalizuje skrupuły.

„Rota PPR

Nie rzucim ziemi skąd nasz ród

Rozkoszne nam pomyje

My PPR-u wierny lud

Potężne mamy ryje

I chcemy Polski aż po Bug

Tak nam dopomóż wróg

Będzie z nas każdy rył i rył

Byle by upaść brzucha

Chociażby cały chlew nam zgnił

MOSKWY będziemy stuchać

Będziemy dąć w sowiecki róg

Tak nam dopomóż wróg

Wśród szczęku broni, huku strzał

Pośród wojennej zgrozy

Opętał nas MOSKIEWSKI szał

By Polsce dać KOŁHOZY

By wszedł KOMUNIZM w każdy próg

Tak nam dopomóż wróg.

${ }^{18}$ Tamże, k. 77, ortografia oryginału. Ulotka powtarza się w niezliczonych odpisach archiwalnych, np. AIPN, Bu 1550/872, 10; ANKr, UW II, 3951, k. 90. 
Cóż że nam każdy pluje w twarz

Żeśmy zdradzili ducha

Choć w mordę bije moskal WSZARZ

My go będziemy słuchać

I będzie Polska aż po Bug

Tak nam dopomóż wróg.

[Podpisano] Wice Prem[ier] GOMUŁKA".

Trop odczłowieczenia zawierają też ulotki „Ognia”. J edna z wielu ma tytuł Żydzi i żydziątka:

„Chcieliście opanować cały kraj,

Zniszczyć Polaków i polskie dzieci,

My wam przygotujemy błogi raj,

Aż parcha żydowska się rozleci.

Żal serce ściska za śmierć Gras[s]grüna ${ }^{19}$,

Za pracę wierną, chytrość zdradziecką,

Wołamy po imieniu, gdzie brudna świnia,

On sprzedał diabłu swą zdolność kupiecką.

Będzie się starał o resztę żydziaków

Aby szczęśliwie i zdrowo poszli do niego,

Miło mu będzie w gronie prosiaków,

Gdy pozna w piekiełku swój swego.

Uchodźcie żydki póki czas,

Palestyna to wasz kraj,

19 Dawid Grassgrün, jedyny uratowany z egzekucji Żydów nowotarskich w roku 1942, zamordowany w lutym 1946 w Nowym Targu, zob. przyp. 16. 
Inaczej zabierzemy wszystkich w las,

I tam będzie błogi raj (...)” (Panz 2015: 51).

O dehumanizacji tak pisze J anina Bauman (2009) w Zimie o poranku:

„W czasie wojny poznałam prawdę, którą na ogół woli się pomijać milczeniem: że najokrutniejszym aktem okrucieństwa jest odczłowieczenie ofiar przed ich unicestwieniem. I że najtrudniejsza ze wszystkich jest walka o pozostanie człowiekiem w nieludzkich warunkach" (za: D: 586).

Antysemityzm i Zagłada

Dającym do myślenia aspektem poglądów Zygmunta Baumana był jego stosunek do antysemityzmu, zakorzeniony w wykładni marksistowskiej. J ego tekst O frustracji i kuglarzach dla paryskiej „Kultury” przypisywał Marzec 68 spiskowi twardogłowych nacjonalkomunistów. Spontaniczny wkład społeczeństwa w marcową nagonkę, wkład, którego doświadczał zarówno on, jak i jego córki, ulega tu całkowitemu zatarciu:

„Antysemickie zabarwienie wydarzeń pomarcowych w Polsce nie jest w żadnym stopniu wynikiem spontanicznego odruchu narodu. J est dziełem rozmyślnym organizatorów prowokacji, za które tylko oni ponoszą odpowiedzialność” (za: D: 453).

Pewna działaczka katolicka, która w 1968 pojechała do Karola Wojtyły prosić o głos Kościoła w sprawie czystek antysemickich ${ }^{20}$, usłyszała tam identyczną opinię: to rywalizacja partyjnych koterii. Zastanawiające, jak zbliżony pogląd miał człowiek, który odczuł jena własnej skórze. Domosławski przytacza jeszcze jedną podobną wypowiedź Baumana:

${ }^{20}$ Zanotowałam po rozmowie z Haliną Bortnowską w roku 2011. 
„Kampania antysemicka 1968 w odróżnieniu od przedwojennego antysemityzmu, to zjawisko czysto polityczne, w którym Żydzi odgrywają rolę kozła ofiarnego, na którym się skupia cała skumulowana agresja i frustracja rozgoryczonych i rozczarowanych mas ludności” (za: D: 462-463) ${ }^{21}$.

J eszcze w roku 2013 Bauman interpretował marzec 68 przez pryzmat mobilizacji „ludowego antysemityzmu” (W: 454). Opis może być prawdziwy, ale ignorując powszechność antysemityzmu wśród inteligencji, socjolog dowodzil, w jak głębokim zaprzeczeniu żyje. Marksistowska wykładnia dawała złudzenie kontroli, a gdy i ono zawiodło, pozwalała otamować kryzys tożsamości. O podobnej ślepocie świadczą dywagacje politologa prof. Wiatra o tym, jak przed marcem 68 my wsie drużno żyli. Wagner ma rację, nazywając to zjawisko polskim antysemityzmem normatywnym (W: 290-291, 375)22.

Zmianę perspektywy Baumana spowodowały dopiero wydane w roku 1986 wspomnienia J aniny Bauman, Winter in the Morning (wyd. pol. Zima o poranku, 1999). Socjolog odpowiedział na nie Nowoczesnościa i Zagłada. Ale również i ta książka, choć odkrywcza i ważna, nie dotknęła polskiego tabu: udziału rodaków w Holokauście (zob. TokarskaBakir 2022). Kierując światło na strukturalne mechanizmy „alienacyjne", odwracała od niego uwagę. Oglądany z dzisiejszej perspektywy komentarz męża do rewelacji żony wygląda trochę jak głos człowieka, który zawsze chce mieć ostatnie słowo.

\footnotetext{
${ }^{21}$ Zob. także opinia Baumana przytaczana przez Janinę Bauman: „Czystki na wysokich stanowiskach to najskuteczniejszy sposób rozładowania napięć. Zwalnia się miejsce na górze, twój szef awansuje, ty awansujesz na jego miejsce, a twój podwładny na twoje. Nic dziwnego, ze ludzie pragną czystek", cyt. za: D: 419.

${ }^{22}$ Autorka, która szeroko omawiała to pojęcie np. 13/10/2020, w czasie prezentacji swojej książki na zebraniu Zakładu Badań Narodowościowych w Instytucie Slawistyki PAN, powinna rozwinąć je w swojej książce. Wspomina je wcześniej w kontekście przedwojnia (W: 234, 235).
} 
Z roku 1989 pochodzi list do Noacha Lasmana, w którym chyba po raz pierwszy Bauman realistycznie ocenia skalę polskiego antysemityzmu (D: 612). Znamienne, że protekcjonalna wyrozumiałość, jaką nawet po wygnaniu socjolog zachował do Polski, nigdy nie objęła Izraela, o którym w roku 1995 napisał coś, co wielu Polakom szczególnie ostatnio (Wysocka-Schnept, Brejdygant 2021) zdarzyło się myśleć o ojczyźnie:

„Ogarnia mnie wprost metafizyczne obrzydzenie. Ten naród nie ma większych wrogów niż on sam. Wszystko jest w Izraelu na sprzedaż: godność, honor i moralność. No i polityka. I przyszłość narodu” (za: D: 501).

Domosławski poświęca tej kwestii sporo miejsca, proporcjonalnie do skandalu, jaki wywołał wywiad z Baumanem dla Polityki w roku 2011. O tym, że nie był to jedynie incydent, przekonałam się w czasie jednej z konferencji otwieranych przez keyspeakera Baumana. Usłyszałam nie tyko porównanie muru na granicy izraelsko-palestyńskiej do tego wokół getta warszawskiego, ale i akceptację zgłoszonego przez kogoś z widowni porównania do ściany krematorium w Auschwitz. Trzeba było wiele dobrej woli, aby w tej ostatniej wypowiedzi rozpoznać rykoszet traumy, przeżytej przez podporucznika Baumana, który na wiosnę 1945 zabezpieczał wyzwolony przez Armię Czerwoną obóz na Majdanku. Przypomina ją Izabela Wagner: „Było to doświadczenie szokujące i tak bolesne, że nigdy nie mówił o nim publicznie” (W: 566).

\section{Profil}

Obie książki różni typ narratora. Obecność Wagner jest bardziej dyskretna. Asystuje życiu, ale pojawia się na jego zapleczu, i tylko za pośrednictwem analitycznych narzędzi. Nie zagłębia się w twórczość, bo to nie biografia intelektualna. Natomiast Domosławski na potrzeby swojej książki stwarza nieco narcystyczną personę dziennikarza, dla którego 
Bauman jest mentorem. Nie zawsze trafnie streszcza jego prace, niejest krytyczny tam, gdzie, moim zdaniem, powinien ${ }^{23}$.

W obu książkach nie podobają mi się zakończenia. U Wagner nietrafna wydaje mi się metafora Zeliga, Baumana- Proteusza. Fakt, żeludzie rozpoznawali w nim tak różne osoby, to nie zaleta ani wada bohatera, ale projekcja nieskończenie różnych umysłów na skończoną pojedynczą osobę. W latach 90. XX wieku młodzi ludzie z otwierającej się Polski pragnęli nie Baumana, ale szczytu, na którym się znalazł. Socjolog był jego twarzą, ale to nie znaczy, że sam miał ,janusowe oblicze”.

Z kolei u Domosławskiego nie przekonuje mnie „wrabianie” socjologa w rolę guru alterglobalizmu. J eśli ją nawet akceptował, to z zastrzeżeniami, bojąc się, że znów wystawią mu rachunek. Pamiętam, że gdy w latach 80. XX wieku pisałam doktorat o soteriologii tybetańskiej, ostrzegał, że metafizyczny ideał kenozy (ogołocenia, wyrzeczenia się świata) łatwo zmienić w postulat społeczny „kenoza dla wszystkich”. I zaprzepaścić ideał oraz własną duszę.

Gdybyjakoś nazwać tę różnicę między biografiami Wagner i Domosławskiego, powiedziałabym, że w jednej życie Zygmunta Baumana jest uważnie czytane, a w drugiej niespiesznie przepisywane ${ }^{24}$. Różnicę tak tłumaczył Walter Benjamin:

„Oddziaływanie gościńca zależy od tego, czy się nim idzie, czy leci nad nim aeroplanem. Podobnie oddziaływanie tekstu zależy od tego, czy się go czyta, czy przepisuje.

\footnotetext{
${ }^{23}$ Mam na myśli ewolucję Baumanowskiej ponowoczesności, którą Domosławski referuje pomijając zamieszanie, jakie wywołała w humanistyce. Gdy okazało się, że zamiast różowych horyzontów czeka nas powrót wypartego, Bauman po prostu przestawił się na „płynną nowoczesność".

24 Oboje autorzy podążają za niepublikowanym tekstem Baumana pt. Polacy, Żydzi i ja. Rozważania nad tym, co uczyniło mnie, kim jestem, co bardzo upodabnia ich narracje.
} 
Lecący widzi tylko, jak droga przebiega wśród krajobrazu, ona zaś odwija mu się według tych samych praw co teren wokół niej. Tylko idący nią doświadcza jej władzy i tego, jak z terenu, będącego dla lotnika tylko rozwiniętą płaszczyzną, przyzywa na komendę każdym zakrętem dale, widoki, prześwity, prospekty - jak dowódca żołnierzy z pozycji frontowych. Tak komenderuje duszą zajmującego się nim tylko tekst przepisywany (...). Dlatego chińskie kopiowanie ksiąg było niezrównaną gwarancją kultury literackiej, a odpis był kluczem do zagadek Chin" (Benjamin 2011: 34, korekta przekładu JTB).

Czytelnik zechce sam ocenić, kto tu czyta, a kto kopiuje.

\section{Powrót wypartego}

Czytanie tych biografii, jedna po drugiej, to osobliwe doświadczenie. Dotyczą jednego fantastycznego życia, opowiedzianego dwukrotnie, w zadziwiająco podobny sposób, $\mathrm{z}$ akcentem na te same progi i zakręty. Czytelnik odczuwa to powtórzenie tak, jakby za pierwszym razem czegoś nie dosłyszał, i powtarzano mu to raz jeszcze. W efekcie zaczyna rozumieć, że Polska to kraj powrotu wypartego.

Ostatnio niemal każdy dzień dowodzi słuszności tej konkluzji. Gnijące, nieprzepracowane dziedzictwo Zagłady, udziału Polaków nieżydowskich w niemieckim projekcie wyniszczenia Żydów, odzywa się w leksyce na polsko-białoruskim pograniczu. Zmartwychwstają stodoły, w których można przenocować, odradzają się "sprawiedliwi”, którzy karmiąc i odziewając narażają się na sąsiedzki gniew. Oraz szmalcownicy, donoszący na nich do władz. Powraca wstrząsająca, przeniesieniowa identyfikacja służb granicznych z historycznym sprawcą (Chołodowski 2021), potwierdzająca się w dewizie SS cytowanej przez ministra polskiego rządu (NaTemat 2021), w Arbeit 
macht frei z występów Konfederacji (Rzeczpospolita 2021), w cynicznym plakacie Wojciecha Korkucia (Olo, jkl, 2017).

Problem narasta, tylko Zygmunta Baumana już nie ma.

Literatura

Bauman, J . (2009). Zima o poranku. Opowieść dziewczynki z warszawskiego getta. Kraków: Znak.

Bauman, Z. (2009). Nowoczesność i Zagłada. Kraków: Wydawnictwo Literackie.

Benjamin, W. (2011). Ulica jednokierunkowa. Warszawa: Aletheia.

Benski, S. (1986) Ocaleni. Warszawa: Czytelnik.

Bilewicz, M. (2009). Sceny z pamięci niczyjej, czyli Rymkiewicza bajki o historii Polska po Goldhagenowsku...Wokół «Legend o krwi«. Res Publica Nowa nr 195.

Buszko, P. (2012). Żyd Żydem. Wizerunek Żyda w kulturze ludowej podlaskich prawostawnych Białorusinów. Miasteczko Orla. Warszawa: Wydawnictwo Agade Bis, Instytut Slawistyki PAN.

Cała, A. (2005). Wizerunek Żyda w polskiej kulturze ludowej. Warszawa: Wydawnictwa Uniwersytetu Warszawskiego.

Chałasiński, J . (1968, 24 marca). Niepokojące zjawiska. Trybuna Ludu. Chołodowski, M. (2021, 19 grudnia). Straż Graniczna „wryfikuje”, czy to jej funkcjonariusze rzucali do wywożonych Syryjczyków: „Jeb..e pi..y, ku..a”. Gazeta Wyborcza: Białystok. https:// bialystok.wyborcza.pl/ bialystok/ 7,35241,27928087,straz-graniczna-weryfikuje-czyto-jej-funkcjonariusze-rzucali.html [19.12.2021]

Dąbrowski, F., Gontarczyk, P., Tomasik, P. (red.) (2018). Marzec 1968 $w$ dokumentach MSW, T.2, cz. 2: Kronika wydarzeń, Warszawa: IPN. 
Domosławski A. (2021). Wygnaniec. 21 scen z życia Zygmunta Baumana. Warszawa: Wielka Litera.

Frankel A. (2007). Dziewczynka. Warszawa: Nisza.

Fitzpatrick Sh. (2020, 10 września). Whatever Made Him. London Review of Books, 42(17). https:// www.lrb.co.uk/ the-pa-

per/v42/n17/ sheila-fitzpatrick/ whatever-made-him [22.12.2021]

Grabski, A. (2012) Problemy z „Żydokomuną” Pawła Śpiewaka. Studia Judaica, $n$ r 1-2.

J akubowski, T. (2021, 20 grudnia). Dziennikarz TOK FM skrytykował Straż Graniczną. Dostał zarzuty zniesławienia. Gazeta Wyborcza. https:// wyborcza.pl/ 7,75398,27934601,dziennikarz-tok-fm-skrytykowal-straz-graniczna-dostal-zarzuty.html [22.12.2021]

Krzemiński, I. (red). (1996). Czy Polacy sq antysemitami? Warszawa: Oficyna Naukowa.

NaTemat (2021, 26 października). Okropne słowa w nowej wiadomości $\mathrm{z}$ afery mailowej. Dworczyk miał użyć dewizy Waffen SS. NaTemat. https:/ / natemat.pl/ 380969, dewiza-waffen-ss-w-wiadomosci-oddworczyka-nowy-etap-afery-mailowej-w-pis [18.12.2021]

Olo, jkl (2017, 14 sierpnia). Skandaliczny plakat „Reparationen machen frei”. Muzeum: Prymitywna manipulacja. Gazety Wyborcza: Kraków. https:/ / krakow.wyborcza.pl/ krakow/ 7,44425,22230443,skandaliczny-plakat-reparationen-machen-frei-muzeum-prymitywna.html [19.12.2021]

Panz K. (2015). Dlaczego oni, którzy tyle przecierpieli i przetrzymali, musieli zginaćc. Żydowskie ofiary zbrojnej przemocy na Podhalu wlatach 1945-1947. Zagłada Żydów. Studia i materiały nr 11.

Rzeczpospolita (2021, 15 grudnia). Muzeum Auschwitz o proteście Konfederacji: Moralne zepsucie. Rzeczpospolita. https:// www.rp.pl/ polityka/ art19197981-muzeum-auschwitz-o-protescie-konfederacjimoralne-zepsucie\#error=login_required\&state=6e001fa2-9c0243ca-8b4a-105309eb3380 [18.12.2021] 
Śpiewak, P. (2012). Żydokomuna. Warszawa: Wydawnictwo Czerwone i Czarne.

Tokarska-Bakir J. (2008). Legendy o krwi, Antropologia przesądu. Warszawa: WAB.

Tokarska-Bakir J . (2016). Polin: Ultimate Lost Object. [w:] Poland and Polin. New Interpretations in Polish-Jewish Studies. (Eds.) Grudzińska-Gross, I., Nawrocki I. Peter Lang.

Tokarska-Bakir (2018). Pod klatwa. Spoleczny portret pogromu kieleckiego. Warszawa: Czarna Owca.

Tokarska-Bakir J. (2022, w druku). The Sociology of Modernity, the Ethnography of the Holocaust: what Zygmunt Bauman knew. [w:] Revisiting Modernity and the Holocaust: Heritage, Dilemmas, Extensions. (Eds.) Palmer, J . \& Brzeziński, D.. New York \& London: Routledge

Wagner, I. (2020). Bauman. A Biography. Cambridge: Polity Press. Wagner, I. (2021). Bauman. Biografia. Warszawa: Czarna Owca. Wysocka-Schnept, D., Brejdygant, S. (2021, 19 grudnia). Krystyna J anda ma rację. J esteśmy obrzydliwi. Gazeta Wyborcza. https:// wyborcza.pl/ 7,82983,27925095,stanislaw-brejdygant-krystyna-janda-ma-racje-jestesmy.html (19.12.2021)

Źródła

Uchwała Sejmu Rzeczypospolitej Polskiej z dnia 9 listopada 2012 r. w związku z 70. rocznicą powstania Narodowych Sił Zbrojnych, „Monitor Polski", 2012, nr 890.

Oświadczenie $w$ sprawie wyborów w Polsce, 1946, Archiwum Narodowe w Krakowie, Zespół WiN 9, k. 279.

Raporty dekadowe, ulotki i inne materiały z 1945-1946, Archiwum Instytutu Pamięci Narodowej, Kr 031/2 t1, k. 38, 77. 
Sprawozdanie informacyjne za miesiąc sierpień 1946. Teren krakowski, ANKr, WiN 4, 157

Ulotka pt. Rota PPR, Archiwum Narodowe w Krakowie, Urząd Wojewódzki II, 3951, k. 90.

Władysław Gomułka, list z 6/1/1944, teczki osobowe, Archiwum Akt Nowych w Warszawie, sygn. 7432, teczka Władysława Gomułki.

Wykaz przestępczości za miesiąc marzec 1946, Powiatowa Komenda MO Referat Śledczy Nowy Sącz, Archiwum Instytutu Pamięci Narodowej, $\mathrm{Kr}$ 140/591. 